\title{
Effects of Vermireactor Modifications on the Welfare of Earthworms Eisenia fetida (Sav.) and Properties of Vermicomposts
}

\author{
Grzegorz Pączka ${ }^{1, *}$, Anna Mazur-Pączka ${ }^{1}$, Mariola Garczyńska ${ }^{1}{ }^{\circledR}$, Joanna Kostecka ${ }^{1}$ and \\ Kevin R. Butt 2 (D) \\ 1 Department of the Basis of Agriculture and Waste Management, Institute of Agricultural Sciences, \\ Land Management and Environmental Protection, College of Natural Sciences, University of Rzeszow, \\ Cwiklinskiej 1a, 35-601 Rzeszow, Poland; anamazur@ur.edu.pl (A.M.-P.); mgar@ur.edu.pl (M.G.); \\ jkosteck@ur.edu.pl (J.K.) \\ 2 School of Natural Sciences, University of Central Lancashire, Preston PR 1 2HE, UK; krbutt@uclan.ac.uk \\ * Correspondence: grzegp@ur.edu.pl; Tel.: +48-17-872-16-65
}

Received: 21 September 2020; Accepted: 15 October 2020; Published: 17 October 2020

\begin{abstract}
Vermicomposting is a method that allows for the environmentally friendly management of plant organic waste through the activity of concentrated earthworm populations. As a result of an appropriately conducted process, it is possible to obtain a valuable organic fertilizer, abundant in nutrients for plants as well as the development of a favorable (qualitatively and quantitatively) earthworm population structure. This paper presents the results of the vermicomposting process of waste plant mass with the use of vermireactors with different designs. In conventional no protective substrate (NPS) vermireactors, plant waste was the only habitat for earthworms, whilst protective substrate (PS) vermireactors also had a medium to shield the earthworm population in the event of the accidental introduction of toxic waste to these invertebrates. A positive effect of the PS vermireactor construction in the protection of an earthworm population against the potential use of stressful waste was found, as populations of Eisenia fetida were monitored and the development was noted during the vermicomposting with both methods. The largest differences between the populations (PS vs. NPS vermireactors) were demonstrated after 40 and 50 days and related to the number of immature animals (PS $>$ NPS by $30.7 \% ; p<0.05$ ) and cocoons (PS $>$ NPS by $34.8 \% ; p<0.05$ ). There were no significant differences between the PS and NPS in the biomass of immature E. fetida and cocoons. The vermicomposts obtained were not significantly different form each other but they were characterized by a higher content of $\mathrm{C}, \mathrm{N}, \mathrm{P}, \mathrm{K}, \mathrm{Ca}$ and $\mathrm{Mg}$ compared to the initial waste biomass. Contents of $\mathrm{Cu}, \mathrm{Mn}, \mathrm{Zn}, \mathrm{Cd}$ and $\mathrm{Pb}$ in vermicomposts did not prevent their use as fertilizers.
\end{abstract}

Keywords: E. fetida; heavy metals; macronutrients; vermicompost; vermireactor; welfare

\section{Introduction}

Recent decades have been characterized by significant and multi-faceted problems related to environmental degradation. Their cause was, among others, improperly managed organic waste, a large part of which is related to the agricultural sector. The growing amount of this waste type has led to work on the creation of more effective, but simultaneously more sustainable waste management systems [1]. Vermicomposting has been proposed as one of the methods of organic waste management and is classified as a biotechnological process that uses selected species of earthworms to improve the waste treatment process and obtain a better final product, i.e., vermicompost. The survival of earthworms in vermiculture, their biomass production and reproduction are the best indicators to assess the quality of the vermicomposting process [2]. 
Due to a shorter waste processing time, vermicomposting is characterized by a greater ability to reduce organic mass compared to traditional composting and generates products with a higher content of humus and much lower phytotoxicity. Microorganisms living in vermicompost and the enzymes produced by earthworms can accelerate the decomposition of organic substances into stable compounds that are easily absorbed by plants [3]. Vermicompost is also more marketable than compost due to its more attractive appearance in addition to higher nutrient content and microbial activity [4].

Global research has been conducted upon the utilization of various organic wastes during the vermicomposting process. These include, for example: vegetable waste [5], waste from grape and olive production [6], apple pomace [7], coconut shells [8], household and kitchen waste [9-11], waste biomass of aquatic plants [12,13], and animal feces [14,15].

The above examples of waste managed in vermiculture, properly selected and prepared, are safe for earthworms. However, in the case of a high content of, e.g., heavy metals, pesticides or other chemical stressors, they may have a negative effect on these invertebrates.

The process of waste neutralizing in vermiculture follows a similar pattern [16-18]. It consists in placing a selected mass of waste (as the sole basis for the life of earthworms) into containers of various sizes and the application of earthworms of various species, numbers and population structures. Although this method is effective in many cases, it can lead to the extinction of entire Lumbricidae populations in a culture, if the organic waste used is toxic to earthworms.

In addition, ethical concerns about the quality of animal life have arisen in recent decades. They have become the subject of public policy and controversy. In discussing the directions of animal welfare research, scientists have proposed different concepts and definitions of animal welfare, which led to different research methods and interpretations of results [19]. The concept of animal welfare includes three basic elements: the natural biological functioning of an animal (meaning the certainty that the animal is healthy and well fed), its emotional state (no negative emotions such as pain and chronic fear), and its ability to express certain standard behaviors and activities [20]. Although the concept of animal welfare refers mainly to vertebrate species with economic use, the authors of this study draw attention to the legitimacy of also creating welfare for invertebrates such as earthworms. This is justified not only in ethical terms but may also contribute to the preservation of the earthworm population in good condition, and thus increase the intensity of waste processing into valuable vermicompost in vermiculture.

The aim of this study was therefore to analyze the effectiveness of modifications in the structure of vermicompost for the preservation of earthworm welfare measured by the development of selected population features of E. fetida and the possibility of producing an organic fertilizer-vermicompost.

\section{Materials and Methods}

\subsection{Research Material}

\subsubsection{Earthworms}

The E. fetida earthworms used in the experiment originated from our own long-term breeding line run at the Department of the Basis of Agriculture and Waste Management at the University of Rzeszów, Poland. Before starting the experiment, mature specimens (with a well developed clitellum) were selected from the culture and placed in containers filled with garden soil and feed for 7 days to acclimatize. This was to eliminate weakened individuals with less tolerance to changing environmental conditions because the use of such earthworms could invalidate the experiment.

\subsubsection{Vegetable Waste-Sugar Beet Pulp}

The sugar beet pulp was obtained from the Ropczyce Sugar Plant (30 km to the west of Rzeszów, Poland). It was frozen for storage, but before starting the experiment, it was thawed at a temperature 
of $20 \pm 1{ }^{\circ} \mathrm{C}$ and dried to allow the application of the same mass of waste to each vermireactor. Before placing in vermireactors, appropriate dry masses were soaked in water for $2 \mathrm{~h}$.

\subsection{Experiment}

\subsubsection{Vermicomposting of Sugar Beet Pulp}

The experiment was carried out in vermireactors constructed from plastic boxes. The bottom of each had small holes made ( $1 \mathrm{~mm}$ diam) to drain the excess water. Each vermireactor was placed in a larger box so that their bottoms were not touching ( $30 \mathrm{~mm}$ spacing) to store any excess water.

Two types of vermireactors of different design were used in the experiment (Figure 1):

(1) Protective substrate (PS) - was constructed of $300 \times 200 \times 200 \mathrm{~mm}$ (length $\times$ width $\times$ height) containers. Vegetable waste in the form of sugar beet pulp (200 $\mathrm{g}$ of dry matter) was placed in plastic nets with the dimensions of $150 \times 200 \times 150 \mathrm{~mm}$ (length $\times$ width $\times$ height) and mesh size $3 \times 4 \mathrm{~mm}$. The nets with plant waste were placed in vermireactors, and the remaining capacity of the vermireactors was filled with a protective soil in the form of horticultural soil universal substrate for ornamental plants: composition: highmoor peat, lowmoor peat, pearlite, sand, microelements, mineral fertilizer NPK universal growing medium Kronen: $\mathrm{pH}$ in $\mathrm{H}_{2} \mathrm{O}$ 6.0-6.5; salinity $\mathrm{NaCl} 4.3 \pm 0.8\left(\mathrm{mg} \cdot \mathrm{kg}^{-1}\right) ; \mathrm{N} 1300 \pm 80\left(\mathrm{mg} \cdot \mathrm{kg}^{-1}\right) ; \mathrm{P} 210 \pm 31\left(\mathrm{mg} \cdot \mathrm{kg}^{-1}\right)$; $\mathrm{K} 620 \pm 82\left(\mathrm{mg} \cdot \mathrm{kg}^{-1}\right) ; \mathrm{Ca} 3423 \pm 97\left(\mathrm{mg} \cdot \mathrm{kg}^{-1}\right) ; \mathrm{Mg} 470 \pm 39\left(\mathrm{mg} \cdot \mathrm{dm}^{-3}\right)$, solid form, loose form, fraction of $0-20 \mathrm{~mm}$.

(2) No protective substrate (NPS) — was constructed of containers with dimensions of $150 \times 200 \times$ $200 \mathrm{~mm}$ (length $\times$ width $\times$ height). Vegetable waste in the form of sugar beet pulp was placed in the same amount ( $200 \mathrm{~g}$ of dry matter) in plastic nets with dimensions of $150 \times 200 \times 150 \mathrm{~mm}$ (length $\times$ width $\times$ height). The nets with waste were placed in vermireactors without the use of a protective substrate.

PS

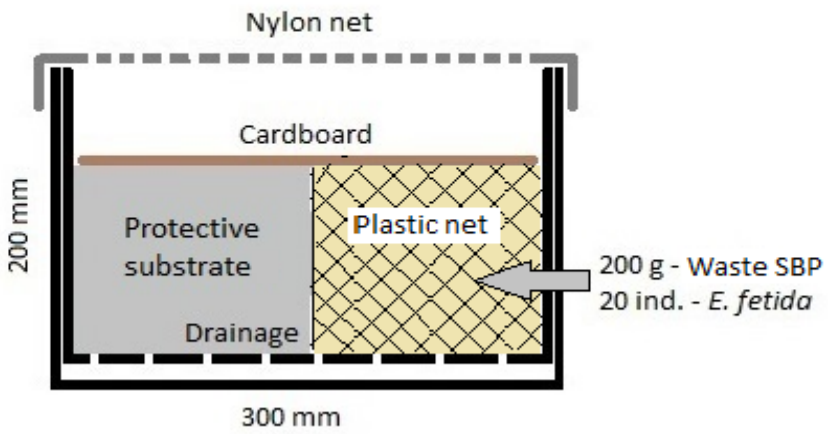

NPS

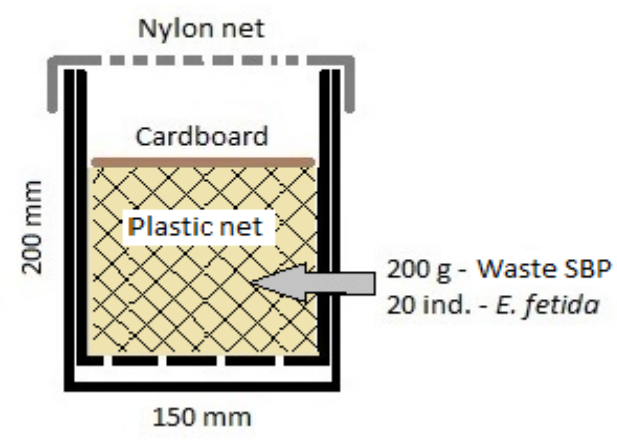

Figure 1. Scheme of the vermireactors (PS- protective substrate; NPS-no protective substrate; Waste SBP—sugar beet pulp).

Only sexually mature earthworms ( $n=20$ per vermireactor) equivalent in terms of numbers and biomass were introduced into the prepared vermireactors of both groups (PS and NPS). They were secured from the top with a nylon mesh, which prevented the escape of earthworms, and with paper cardboard preventing the soil from drying out (Figure 1). The experiment was carried out in an air-conditioning chamber at a temperature of $20{ }^{\circ} \mathrm{C} \pm 0.5^{\circ} \mathrm{C}$. To maintain appropriate humidity inside the vermireactors, they were moistened every 10 days with water ( $\mathrm{pH} 7.6$, conductivity $542 \mu \mathrm{S} \mathrm{cm}^{-1}$, nitrates (V) $8.9 \mathrm{mg} \mathrm{L}^{-1}, \mathrm{Mg} 15.7 \mathrm{mg} \mathrm{L}^{-1}$, hardness $257 \mathrm{mg} \mathrm{CaCO}_{3} \mathrm{~L}^{-1}$ ); vermireactors capacities PS $200 \mathrm{~mL}$, NPS $100 \mathrm{~mL}$.

The experiment included 5 replicates of sugar beet pulp waste mass vermicomposting in each group of vermireactors according to the following scheme: 
- 5 PS vermireactors (200 g sugar beet pulp $+4.5 \mathrm{dm}^{3}$ protective substrate +20 mature E. fetida individuals);

- 5 NPS vermireactors (200 g sugar beet pulp +20 mature E. fetida individuals).

\subsubsection{Analysis of the Protective Substrate Application Effectiveness}

To assess the suitability of using a protective substrate in the construction of vermireactors, additional, identical vermireactors as in the PS group were used in the experiment (Figure 2).

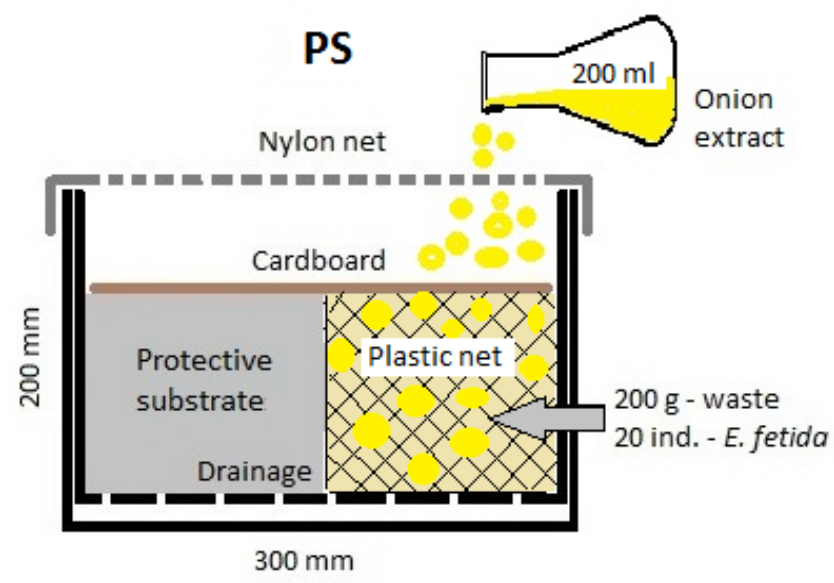

Figure 2. Control of the protective medium effectiveness in PS vermireactors.

Sexually mature earthworms equivalent in terms of their numbers and biomass were introduced into the boxes containing sugar beet pulp waste. Then, to create stressful conditions for earthworms, $200 \mathrm{~mL}$ of onion extract was poured over the sugar beet pulp with earthworms. To obtain the onion extract, a white-leaved onion species (Allium cepa L.) was used, and prepared at the concentration recommended for flushing earthworms out of the soil [21] according to the scheme: $700 \mathrm{~g}$ of onion $+0.5 \mathrm{~L}$ of water, blended, and the volume was completed to $4 \mathrm{~L}$ of water. Each time, $48 \mathrm{~h}$ after the application of the stressor, the number and condition of earthworms in the waste and those that had moved to the protective substrate, were analyzed by manual segregation.

The experiment was conducted 5 times, each time with 5 replicates.

\subsubsection{E. fetida Population Analysis}

Inspections of earthworm population status were performed every 10 days. They consisted of the manual segregation of the substrate and waste to analyze the number and biomass of mature specimens, young individuals and cocoons.

\subsubsection{Physicochemical Analysis of Sugar Beet Pulp (SBP) Waste and Vermicomposts}

The contents of macroelements $(\mathrm{N}, \mathrm{P}, \mathrm{K}, \mathrm{Ca}, \mathrm{Mg}$ ) were determined in the plant material and vermicompost. Nitrogen was determined by the Kjeldahl method; phosphorus-colorimetrically by the vanadium-molybdenum method, potassium, magnesium and calcium-using atomic absorption spectrophotometry after prior mineralization of the sample in a mixture of concentrated mineral acids $\left(\mathrm{HNO}_{3}: \mathrm{HClO}_{4}: \mathrm{H}_{2} \mathrm{SO}_{4}\right.$ in the ratio 20:5:1); carbon was determined using the Vario EL-CUBE elemental analyzer (Elementar, Langenselbold, Germany); micronutrients ( $\mathrm{Mn}, \mathrm{Zn}, \mathrm{Cu}$ ) were determined by the AAS technique, and toxic trace metals ( $\mathrm{Pb}$ and $\mathrm{Cd}$ ) - after concentrating in the organic phase of methyl isobutyl ketone (MBIK); the $\mathrm{pH}$ in water was determined by potentiometry; salt concentration - by conductometric method [22]; the $\mathrm{C} / \mathrm{N}$ ratio in waste and vermicomposts was also calculated. 


\subsection{Statistical Analysis}

All statistical analyses were expressed as the mean of five replicates using the computer software package Statistica 13.1 (Dell, Round Rock, TX, USA). Tukey's t test was used as a post hoc analysis to compare the means. One-way analysis of variance (ANOVA) was used to analyze the significant difference between different research groups for the observed monitoring parameters and the significant difference between heavy metal contents in the initial biomass and vermicomposts.

\section{Results and Discussion}

\subsection{Changes in E. fetida Populations}

Maintaining the appropriate welfare of earthworms, which can be measured by their population development, seems to be a key element in the effective vermicomposting of plant organic matter and in obtaining vermicompost abundant in plant nutrients. As the present study shows, the populations of earthworms in the PS and NPS groups developed. Although a decrease in the mean number of mature E. fetida individuals was found (by $2 \%$ in the PS and NPS groups) (Figure 3a), it was not significant $(p>0.05)$ and probably had no effect on the development of the population and the course of the vermicomposting process. Significant differences were observed in the mean biomass of mature earthworms between the PS and NPS groups from the 10th to 40th day of the vermicomposting process ( $23 \%$ on average; $p<0.05)$. In both groups, an initial increase in the mean biomass of mature specimens was also noted, followed by a gradual decrease (difference between the 10th and 40th day in the PS and NPS vermireactors by $28.6 \%$ and $27.7 \%$, respectively; $p<0.05$ ) (Figure $3 \mathrm{~d}$ ). A decrease in the growth rate of E. fetida during the vermicomposting process was also found by Sangwan et al. [23], who vermicomposted industrial sludge.

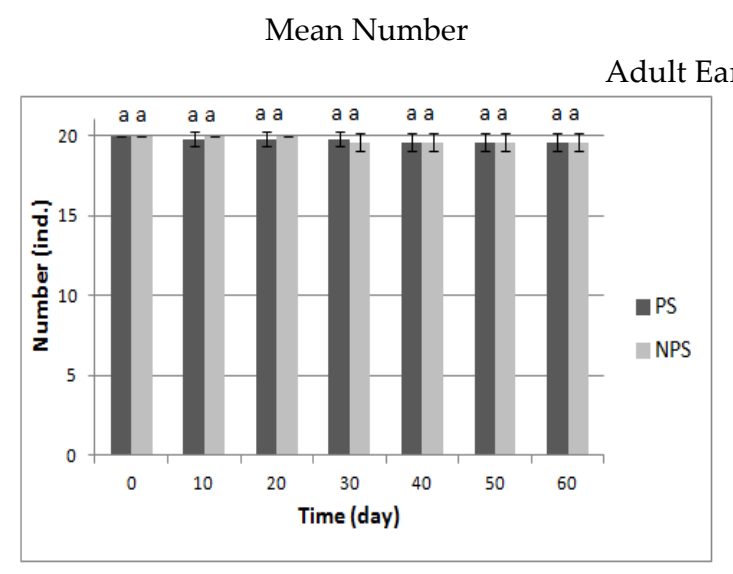

(a)
Mean Individual Biomass



(d)

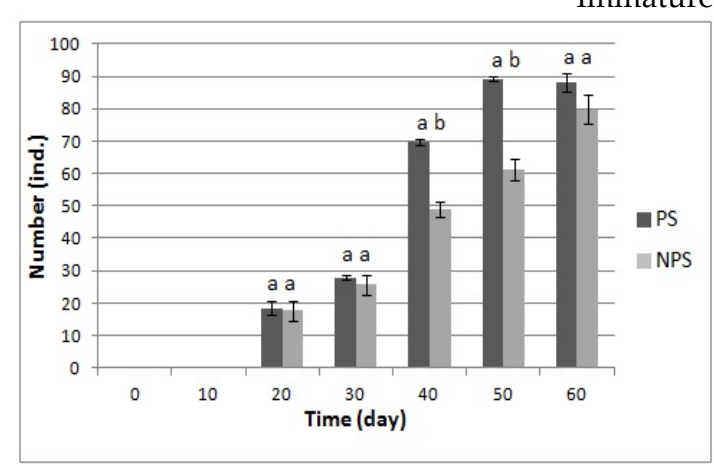

(b)



(e)

Figure 3. Cont. 
Cocoons

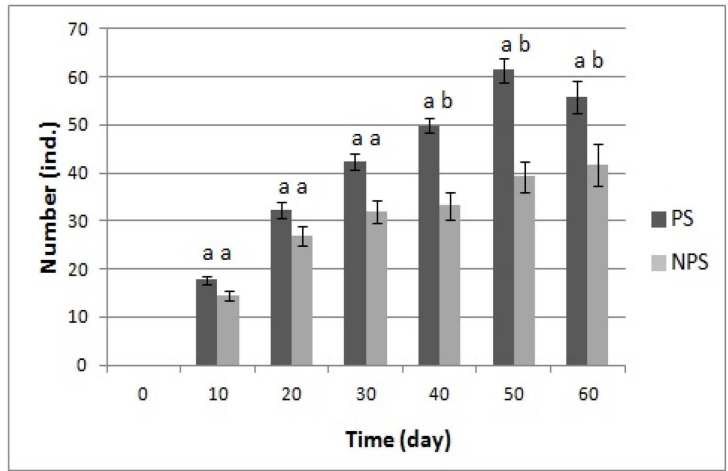

(c)

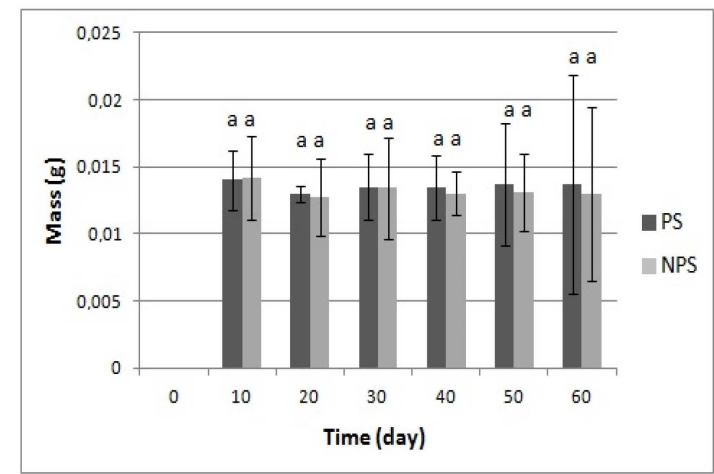

(f)

Figure 3. Dynamics of the mean number and mean biomass (g) of adult specimens (a,d), immature specimens $(\mathbf{b}, \mathbf{e})$ and cocoons $(\mathbf{c}, \mathbf{f})$ of E. fetida in the process of vermicomposting sugar beet pulp in modified vermireactors. Values designate the mean \pm standard deviation based on 5 samples. Mean values with different letters are statistically different $(p<0.05)$.

Development of an earthworm population is determined by the reproductive potential of its members. The present study shows that E. fetida individuals in both PS and NPS groups multiplied. However, significant differences were observed in the number of cocoons produced and the number of immature individuals between the methods of vermireactor management (Figure $3 b, c$ ), with no significant differences in their biomass (Figure 3e,f). The most considerable differences in the number of cocoons produced between the PS and NPS groups were found from day 40 to day 60 of the vermicomposting process (average difference of $31.6 \% ; p<0.05$ ). The largest increase in the number of cocoons produced occurred between the 10th and the 20th day (PS increase by $81 \%$; $p<0.05$, NPS increase by $87 \% ; p<0.05$ ) (Figure 3c). Mean cocoon production by earthworms during the experiment was $2.19 \pm 0.83$ and $1.59 \pm 0.51$ cocoons worm $^{-1}$ in the PS and NPS groups, respectively. Maximum cocoon production was demonstrated in PS vermireactors on day 50 of the process $\left(3.14 \pm 0.15\right.$ cocoons worm $\left.{ }^{-1}\right)$, whilst this was on day $60\left(2.13 \pm 0.04\right.$ cocoons worm $\left.^{-1}\right)$ in NPS vermireactors (Table 1$)$.

Table 1. Dynamics of cocoon production by E. fetida (cocoons worm ${ }^{-1}$ ) over time (days in bold) depending on the technology (PS or NPS) used in the construction of vermireactors.

\begin{tabular}{cccccccc}
\hline & $\mathbf{1 0}$ & $\mathbf{2 0}$ & $\mathbf{3 0}$ & $\mathbf{4 0}$ & $\mathbf{5 0}$ & $\mathbf{6 0}$ & Mean $\pm \mathbf{s d}$ \\
\hline PS & $0.89 \pm 0.04 \mathrm{a}$ & $1.63 \pm 0.05 \mathrm{a}$ & $2.14 \pm 0.09 \mathrm{a}$ & $2.54 \pm 0.07 \mathrm{a}$ & $3.14 \pm 0.15 \mathrm{a}$ & $2.85 \pm 0.08 \mathrm{a}$ & $2.19 \pm 0.83 \mathrm{a}$ \\
\hline NPS & $0.72 \pm 0.05 \mathrm{a}$ & $1.35 \pm 0.06 \mathrm{a}$ & $1.62 \pm 0.04 \mathrm{a}$ & $1.69 \pm 0.06 \mathrm{~b}$ & $2.00 \pm 0.07 \mathrm{~b}$ & $2.13 \pm 0.04 \mathrm{~b}$ & $1.59 \pm 0.51 \mathrm{~b}$ \\
\hline \% difference & 19.1 & 17.2 & 24.3 & 33.5 & 36.3 & 25.3 & 27.4
\end{tabular}

Values designate the mean \pm standard deviation based on 5 samples. Mean value followed by different letters is statistically different $(p<0.05)$.

Flack and Hartenstein [24] showed that the production of cocoons by earthworms can be greatly influenced by the biochemical composition of the waste they process. In the present experiment, plant waste with the same physicochemical characteristics was used in the PS and NPS vermireactors, but the PS group had a protective substrate in the form of biologically active horticulture soil, in which most cocoons laid by earthworms were found (Table 2). This may indicate that E. fetida earthworms, in addition to adequate food mass, also need another space for population development where they will find better conditions, e.g., for reproduction. Suthar [25] reported that apart from the feed quality, the biomass of microorganisms in the substrate may also affect the reproduction of earthworms. 
Table 2. Distribution of the number of mature individuals, immature individuals and cocoons of E. fetida in the protective substrate (PS) and the sugar beet pulp (SBP) waste mass during the inspection of the earthworm population status.

\begin{tabular}{cccccc}
\hline \multirow{2}{*}{ Day of Experiment } & E. fetida & Protective Substrate (PS) & Waste SBP & \multicolumn{2}{c}{ Percentage } \\
PS & SBP \\
\hline \multirow{2}{*}{10} & Adult & $5.6 \pm 1.14 \mathrm{a}$ & $14.2 \pm 1.30 \mathrm{~b}$ & 28.6 & 71.4 \\
& Immature & 0 & 0 & 0 & 0 \\
& Cocoons & $13.0 \pm 1.22 \mathrm{a}$ & $4.8 \pm 0.84 \mathrm{~b}$ & 73.0 & 27.0 \\
\hline \multirow{2}{*}{20} & Adult & $5.4 \pm 1.52 \mathrm{a}$ & $14.4 \pm 1.52 \mathrm{~b}$ & 27.3 & 72.7 \\
& Immature & $6.4 \pm 2.07 \mathrm{a}$ & $12.0 \pm 2.55 \mathrm{~b}$ & 34.8 & 65.2 \\
& Cocoons & $23.8 \pm 3.96 \mathrm{a}$ & $8.4 \pm 2.88 \mathrm{~b}$ & 73.9 & 26.1 \\
\hline \multirow{3}{*}{30} & Adult & $6.0 \pm 1.00 \mathrm{a}$ & $13.8 \pm 1.30 \mathrm{~b}$ & 30.3 & 69.7 \\
& Immature & $6.0 \pm 1.00 \mathrm{a}$ & $21.8 \pm 1.64 \mathrm{~b}$ & 21.6 & 78.4 \\
& Cocoons & $32.6 \pm 2.70 \mathrm{a}$ & $9.8 \pm 3.56 \mathrm{~b}$ & 76.9 & 23.1 \\
\hline \multirow{3}{*}{40} & Adult & $5.4 \pm 2.07 \mathrm{a}$ & $14.2 \pm 1.92 \mathrm{~b}$ & 27.6 & 72.4 \\
& Immature & $13.4 \pm 2.88 \mathrm{a}$ & $56.2 \pm 3.27 \mathrm{~b}$ & 19.3 & 80.7 \\
& Cocoons & $40.0 \pm 3.81 \mathrm{a}$ & $9.8 \pm 3.42 \mathrm{~b}$ & 80.3 & 19.7 \\
\hline \multirow{2}{*}{50} & Adult & $5.8 \pm 0.84 \mathrm{a}$ & $13.8 \pm 0.84 \mathrm{~b}$ & 29.3 & 70.7 \\
& Immature & $15.6 \pm 3.71 \mathrm{a}$ & $73.8 \pm 4.09 \mathrm{~b}$ & 17.4 & 82.6 \\
& Cocoons & $46.6 \pm 2.97 \mathrm{a}$ & $14.8 \pm 3.70 \mathrm{~b}$ & 75.9 & 24.1 \\
\hline \multirow{2}{*}{60} & Adult & $4.8 \pm 1.30 \mathrm{a}$ & $14.8 \pm 0.84 \mathrm{~b}$ & 24.5 & 75.5 \\
& Immature & $17.2 \pm 4.02 \mathrm{a}$ & $70.4 \pm 5.22 \mathrm{~b}$ & 19.6 & 80.4 \\
& Cocoons & $44.6 \pm 4.09 \mathrm{a}$ & $11.2 \pm 3.77 \mathrm{~b}$ & 79.9 & 20.1 \\
\hline
\end{tabular}

Values designate the mean \pm standard deviation based on 5 samples. Mean value followed by different letters is statistically different $(p<0.05)$.

Differences in the numbers of young E. fetida were the consequences of significant differences in cocoon production between the methods of vermireactor production. Significant differences between the PS and NPS groups were found on day 40 (difference by $29.8 \% ; p<0.05$ ) and day 50 (difference by $31.5 \% ; p<0.05$ ) of the vermicomposting process (Figure $3 b$ ). However, no significant differences were found between the PS and NPS groups in the mean weight of young animals (Figure 3e).

Upon the inspection of vermireactor earthworm populations, it was found that the majority of mature (average $72.1 \%$ ) and immature (average 77.5\%) individuals were present in the waste mass of sugar beet pulp. However, the highest number of cocoons was found in the protective substrate (76.7\% on average) (Table 2). This tendency may indicate that the time of analysis of the E. fetida population in vermireactors (always at a similar time-morning hours) coincided with the feeding time of earthworms, while the applied protective medium was an appropriate place for annelid reproduction.

\subsection{Analysis of the Protective Substrate Application Effectiveness}

As this study shows, after applying the stressor in the form of onion extract to earthworm populations, on average $96.2 \%$ of individuals migrated to the protective medium to avoid its irritating effect (Figure 4). There was also a 100\% survival rate for earthworms (including those that did not leave the stressor substrate) (Figure 4). This was probably since the concentration of onion extract recommended by Steffen et al. [21] is supposed to irritate the bodies of earthworms without leading to their death. However, in the case of using improperly selected or prepared organic waste in vermiculture, the protective substrate may contribute to the protection of the earthworm population against extinction. 
$[\%\}$

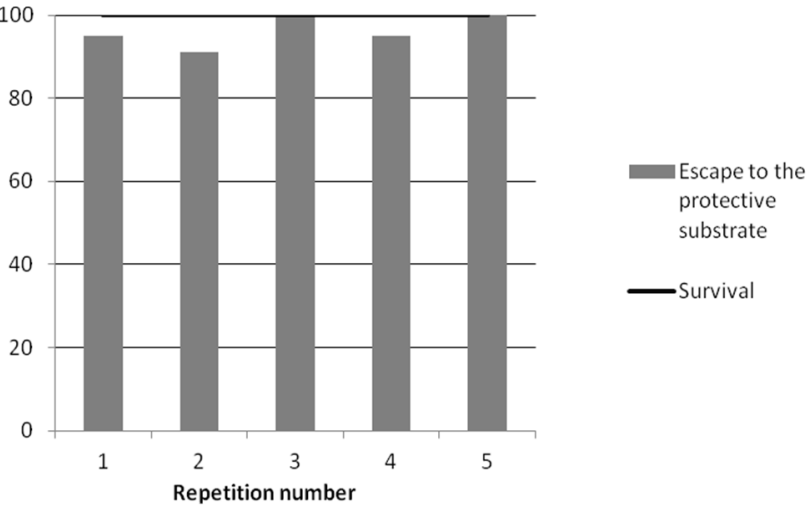

Figure 4. Reaction of E. fetida individuals to the stressor and their survival.

Earthworms are organisms that can tolerate the effects of some environmental stressors, but this occurs within a certain range of ecological tolerance. For example, Reinecke et al. [26] reported that the population of E. fetida, that had been exposed to elevated concentrations of cadmium for over 10 generations, survived higher concentrations of this element than organisms previously not exposed to this stressor. In turn, Takacs et al. [27] found a negative effect of Cd on the maturation of individuals and cocoon production in E. andrei. Spurgeon and Hopkin [28] observed an increased resistance of E. fetida to the toxic effects of zinc. Neuhauser et al. [29] and van Gestel et al. [30] showed that low concentrations of essential trace elements such as cobalt or copper in the diet of earthworms can stimulate both their growth and reproduction, while higher concentrations of the same elements have a destructive effect. Klok and De Roos [31] and Ma [32] found the negative effect of higher concentrations of copper on the growth and reproduction of Lumbricus rubellus. The studies by Owojori et al. [33] showed that an increase in the salinity of the growing medium as a serious stress reduced the average weight of E. fetida earthworms and the average number of cocoons they produced. Fisher and Molnar [34] showed a negative effect of an increase in $\mathrm{NaCl}$ salinity on cocoon production in E. fetida.

\subsection{Physicochemical Properties of Waste and Vermicomposts}

Numerous studies show that the process of vermicomposting modifies the physical, chemical and biological properties of the waste plant mass processed by earthworms $[12,35,36]$.

The type and method of plant waste preparation and conditions in which the vermicomposting process takes place have a large impact on the fertilizing value of the vermicompost obtained. Therefore, it is important to know the physicochemical composition of both the processed initial waste and the vermicompost to determine its suitability for use as a fertilizer.

As a result of vermicomposting, significant changes in the $\mathrm{pH}$ value were observed between the initial biomass SBP and the obtained vermicomposts. The $\mathrm{pH}$ value of the sugar beet pulp waste mass decreased from slightly alkaline (7.07 \pm 0.09$)$ to slightly acidic (PS group $6.29 \pm 0.17$ and NPS group $5.94 \pm 0.89)(p<0.05)$ (Table 3). Similar observations were made by Ndegwa and Thompson [37], who showed that the change in the $\mathrm{pH}$ value may be caused by the mineralization of $\mathrm{N}$ and $\mathrm{P}$ and the conversion of organic material into an organic acid intermediate. According to Pramanik et al. [38], changes in the $\mathrm{pH}$ value in vermicompost may be related to the decomposition of organic matter, which leads to the formation of ammonium $\left(\mathrm{NH}_{4}{ }^{+}\right)$and humic acids. The combined effect of these interactions can lead to a shift in $\mathrm{pH}$ toward neutrality or acidity. In this study, no significant differences in the values of the discussed feature were found between the vermicomposts obtained with the use of different methods of vermireactors (Table 3). 
Table 3. Content of macronutrients in sugar beet pulp and obtained vermicomposts.

\begin{tabular}{|c|c|c|c|c|}
\hline Parameter & Units & & PS & NPS \\
\hline \multirow{3}{*}{$\mathrm{C}$} & \multirow{18}{*}{ 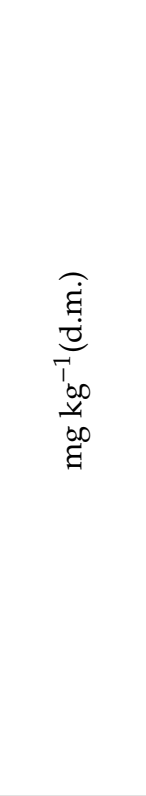 } & Initial & 206321. & $3689.2 \mathrm{a}$ \\
\hline & & Final & $98189.8 \pm 2699.7 b$ & $99391.7 \pm 2811.4 b$ \\
\hline & & $\%$ of change & -52.4 & -51.8 \\
\hline \multirow{3}{*}{$\mathrm{N}$} & & Initial & \multicolumn{2}{|c|}{$3851.4 \pm 33.4 \mathrm{a}$} \\
\hline & & Final & $4964.2 \pm 49.5 \mathrm{~b}$ & $4610.1 \pm 93.4 \mathrm{~b}$ \\
\hline & & $\%$ of change & 28.9 & 19.7 \\
\hline \multirow{3}{*}{$\mathrm{P}$} & & Initial & \multicolumn{2}{|c|}{$114.9 \pm 13.2 \mathrm{a}$} \\
\hline & & Final & $289.4 \pm 28.1 \mathrm{~b}$ & $263.7 \pm 44.1 \mathrm{~b}$ \\
\hline & & $\%$ of change & 151.9 & 129.5 \\
\hline \multirow{3}{*}{ K } & & Initial & \multicolumn{2}{|c|}{$2778.3 \pm 86.6 \mathrm{a}$} \\
\hline & & Final & $3509.2 \pm 71.1 \mathrm{~b}$ & $3489.7 \pm 95.8 \mathrm{~b}$ \\
\hline & & $\%$ of change & 26.3 & 25.6 \\
\hline \multirow{3}{*}{$\mathrm{Ca}$} & & Initial & \multicolumn{2}{|c|}{$1486.3 \pm 35.1 \mathrm{a}$} \\
\hline & & Final & $1911.8 \pm 29.5 \mathrm{~b}$ & $1883.1 \pm 95.8 b$ \\
\hline & & $\%$ of change & 28.6 & 26.7 \\
\hline \multirow{3}{*}{$\mathrm{Mg}$} & & Initial & \multicolumn{2}{|c|}{$163.9 \pm 12.2 \mathrm{a}$} \\
\hline & & Final & $266.8 \pm 29.4 b$ & $261.1 \pm 85.6 b$ \\
\hline & & $\%$ of change & 62.8 & 59.3 \\
\hline \multirow{3}{*}{$\mathrm{C} / \mathrm{N}$ ratio } & \multirow{3}{*}{-} & Initial & \multicolumn{2}{|c|}{$53.57 \pm 9.78 \mathrm{a}$} \\
\hline & & Final & $19.78 \pm 1.16 \mathrm{~b}$ & $21.56 \pm 1.09 \mathrm{~b}$ \\
\hline & & $\%$ of change & -63.1 & -59.8 \\
\hline \multirow{3}{*}{$\mathrm{pH}$ in $\mathrm{H}_{2} \mathrm{O}$} & \multirow{3}{*}{ - } & Initial & \multicolumn{2}{|c|}{$7.07 \pm 0.09 a$} \\
\hline & & Final & $6.29 \pm 0.17 b$ & $5.94 \pm 0.89 b$ \\
\hline & & $\%$ of change & -12.4 & -19.0 \\
\hline \multirow{3}{*}{ Electrical conductivity } & \multirow{3}{*}{$\mathrm{mS} \cdot \mathrm{cm}^{-1}$} & Initial & \multicolumn{2}{|c|}{$1.74 \pm 0.05 \mathrm{a}$} \\
\hline & & Final & $2.36 \pm 0.07 b$ & $2.17 \pm 0.03 b$ \\
\hline & & $\%$ of change & 35.6 & 24.7 \\
\hline
\end{tabular}

Values designate the mean \pm standard deviation based on 5 samples. Mean value followed by different letters is statistically different $(p<0.05)$.

There were also no significant differences in the electrical conductivity (EC) for the vermicomposts. However, significant differences were demonstrated between the initial biomass and the vermicomposts produced, from both the PS and NPS groups (differences by $35.6 \%$ and $24.7 \%$, respectively; $p<0.05$ ) (Table 3). The increase in EC could be due to the release of various mineral ions such as phosphates, ammonium, potassium and others [39].

\subsubsection{Macronutrients Content}

As a result of the 60 day vermicomposting of sugar beet pulp with the use of various vermicomposting technologies, no significant differences in the $\mathrm{C} / \mathrm{N}$ ratio were found between the vermicomposts. A significant decrease in the value of the analyzed features was observed between the waste initial biomass and vermicomposts from the PS and NPS groups (decreased by $63.1 \%$ and $59.8 \%$, respectively; $p<0.05$ ) (Table 3 ).

The $\mathrm{C} / \mathrm{N}$ ratio in the vermicomposts from the PS group was $19.78 \pm 1.16$, in the NPS group $21.56 \pm 1.09$, i.e., according to Sharma and Garg [16], these values indicate the acceptable maturity of the vermicomposts obtained. The $\mathrm{C} / \mathrm{N}$ ratio is the most commonly used indicator of vermicompost maturity and indicates the degree of mineralization and stabilization of the waste plant mass. Depending on the advancement of the vermicomposting process, carbon is lost through the mineralization of labile organic compounds and in the form of $\mathrm{CO}_{2}$ as a result of the microorganisms' respiration with a simultaneous increase in nitrogen content as a result of, among others, the physiological processes of 
earthworms $[7,40]$. In this study, an appropriate degree of organic matter stabilization was obtained in all vermireactors, which demonstrates that the waste mass of sugar beet pulp can be processed into vermicompost using E. fetida earthworms in PS construction vermireactors.

The $\mathrm{N}$ content of vermicomposts was at a similar level and did not differ significantly (difference between the PS and NPS groups was $7 \% ; p>0.05$ ). However, a significant difference in the content of this element was shown between the initial biomass and vermicomposts from the PS group (increase from $3851.4 \pm 33.4$ to $4964.2 \pm 49.5 \mathrm{mg} \mathrm{kg}^{-1} ; p<0.05$ ) and the NPS group (increase from $3851.4 \pm 33.4$ to $4610.1 \pm 93.4 \mathrm{mg} \mathrm{kg}^{-1} ; p<0.05$ ) (Table 3). According to Viel et al. [41], carbon losses may be responsible for the increase in the nitrogen content. Whereas Plaza et al. [42] report that nitrogen retention in vermicompost may result in lowering the $\mathrm{pH}$, while with increasing $\mathrm{pH}$, this element may be lost in the form of ammonia.

As a result of vermicomposting sugar beet pulp, a significant increase in the P content was found (in PS vermireactors-an increase of $151.9 \%$, in NPS vermireactors-an increase of $129.5 \% ; p<0.05$ ) (Table 3). There were no significant differences in the content of this element between vermicomposts. This study confirms the observations of Deka et al. [43], who showed a $63.4 \%$ increase in available phosphorus as a result of the P mineralization in the mass of waste. Phosphorus is an essential component of valuable vermicompost and plays an important role plant growth and development. Ghosh et al. [44] reported that vermicomposting can be an effective method of transforming the forms of phosphorus unavailable to plants into easily digestible forms. Prakash and Karmegam [45] claim that the increase in the content of phosphorus in vermicompost may be caused, among others, by microorganisms developing in earthworm coprolytes.

There were no significant differences in the content of $\mathrm{K}$ in the vermicomposts, while an increase in this element relating to the initial biomass was observed. In the vermicompost obtained in the PS technology, the K content increased by $26.3 \%(p<0.05)$ to the mean level of $3509.2 \pm 71.1 \mathrm{mg} \mathrm{kg}^{-1}$, while in the NPS group, there was an increase of $25.6 \%(p<0.05)$ to the average level of $3489.7 \pm 95.8 \mathrm{mg} \mathrm{kg}^{-1}$. A similar increase in the content of this element in vermicompost was found by Paczka et al. [12] —an increase relating to the initial biomass by $(260-590 \%)$ and Suthar [40] —an increase of (100-160\%). Kaviraj and Sharma [39] argue that microorganisms living in the gut of earthworms may play an important role in the increase in potassium content during vermicomposting.

A similar situation was observed with calcium (Ca) where there were no significant differences between the vermicomposts. A significant increase in Ca content was recorded between the vermicomposts and the initial biomass (in the PS group-an increase of $28.6 \% ; p<0.05$, in the NPS group-an increase of $26.7 \% ; p<0.05$ ) (Table 3). Similar observations were presented by Deka et al. [43] and Suthar et al. [46]. Suthar and Sharma [47] reported that earthworms contribute to the increase in the content of easily available forms of Ca in vermicompost, and therefore in this respect, vermicomposting technology is better than traditional composting. In turn, Puyuelo et al. [48] claim that the increase in Ca content in vermicomposts may be the result of a combined action of fungi and earthworms.

In this study, a significant increase was found in the content of magnesium $(\mathrm{Mg})$ in vermicomposts in comparison to the initial weight of sugar beet pulp. After 60 days of vermicomposting in the PS group, there was a $62.8 \%$ increase in $\mathrm{Mg}$ from $163.9 \pm 12.2 \mathrm{mg} \mathrm{kg}^{-1}$ to $266.8 \pm 29.4 \mathrm{mg} \mathrm{kg}^{-1}$ $(p<0.05)$, in the NPS group-59.3\% increase to $261.1 \pm 85.6 \mathrm{mg} \mathrm{kg}^{-1}(p<0.05)$. Das et al. [49] and Puyuelo et al. [48] indicate that, as for Ca, the combined action of earthworms (detritophages) and fungi (reducers) may have a large impact on the increase in $\mathrm{Mg}$ content in vermicompost.

\subsubsection{Heavy Metals Contents}

Heavy metals are characterized by the possibility of a long retention time in the soil, from where they are taken up by consumer plants and consequently, can cause health problems for animals and humans through their consumption [50]. Although the content of most of the analyzed heavy metals in the vermicomposts increased significantly (Table 4$)(p<0.05)$ compared to the initial biomass, this does not disqualify their fertilization suitability, as their level does not exceed the permissible content of 
these elements in composts in EU countries [51]. There were no significant differences in the content of the analyzed elements between the vermicomposts (Table 4).

Table 4. Microelement contents in plant waste and the obtained vermicomposts.

\begin{tabular}{|c|c|c|c|c|}
\hline Properties & Units & Characterized Substrates & PS & NPS \\
\hline \multirow{3}{*}{$\mathrm{Cu}$} & \multirow{15}{*}{ 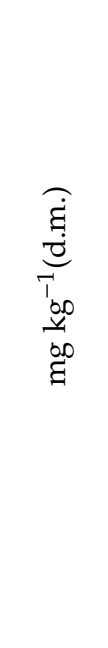 } & Initial & \multicolumn{2}{|c|}{$22.3 \pm 4.1 \mathrm{a}$} \\
\hline & & Final & $45.9 \pm 6.4 b$ & $47.1 \pm 11.3 b$ \\
\hline & & $\%$ of change & 105.8 & 111.2 \\
\hline \multirow{3}{*}{ Mn } & & Initial & 456.3 & $27.1 \mathrm{a}$ \\
\hline & & Final & $388.1 \pm 19.7 \mathrm{~b}$ & $362.5 \pm 21.1 \mathrm{~b}$ \\
\hline & & $\%$ of change & -15.0 & -20.6 \\
\hline \multirow{3}{*}{$\mathrm{Zn}$} & & Initial & \multicolumn{2}{|c|}{$19.5 \pm 2.7 \mathrm{a}$} \\
\hline & & Final & $51.7 \pm 9.1 \mathrm{~b}$ & $56.2 \pm 9.9 b$ \\
\hline & & $\%$ of change & 165.1 & 188.2 \\
\hline \multirow{3}{*}{$\mathrm{Cd}$} & & Initial & \multicolumn{2}{|c|}{$0.7 \pm 0.0 \mathrm{a}$} \\
\hline & & Final & $0.9 \pm 0.1 \mathrm{~b}$ & $0.9 \pm 0.1 b$ \\
\hline & & $\%$ of change & 28.6 & 28.6 \\
\hline \multirow{3}{*}{$\mathrm{Pb}$} & & Initial & \multicolumn{2}{|c|}{$1.1 \pm 0.1 \mathrm{a}$} \\
\hline & & Final & $0.6 \pm 0.1 b$ & $0.5 \pm 0.1 \mathrm{~b}$ \\
\hline & & $\%$ of change & -45.5 & -54.5 \\
\hline
\end{tabular}

Values designate the mean \pm standard deviation based on 5 samples. Mean value followed by different letters is statistically different $(p<0.05)$.

Deolalikar et al. [52] and Hait and Tare [53] reported that the increase in heavy metal content in vermicompost may result from a reduction in the volume and weight of the final product. Results concerning the increase in the concentration of heavy metals in vermicomposts compared to the initial biomass were presented by Yuvaraj et al. [54], Bhat et al. [55] and Gupta and Garg [56].

A decrease in the content between the initial biomass and vermicomposts obtained in the PS and NPS technologies was recorded relating to $\mathrm{Pb}$ (decrease of $45.5 \%$ and $54.5 \%$, respectively; $p<0.05$ ) and Mn (decrease of $15 \%$ and $20.6 \%$, respectively; $p<0.05$ ) (Table 4 ). Reduction in the concentration of these elements in vermicompost may be, among others, caused by the fact that some metal fractions readily bio-accumulate in earthworm tissues [57]. According to Singh and Kalamdhad [58], Mn is necessary for the proper development of plants, but a high concentration may be toxic to living organisms. This element, at a $\mathrm{pH}$ of the substrate below 5.5, may cause damage to the assimilation apparatus, which is dangerous for plants [59]. By contrast, lead $(\mathrm{Pb})$ is considered a poison that accumulates and has a slow but long-lasting effect on living organisms. The toxic effect of lead on plants causes their underdevelopment by inhibiting root growth and chlorosis. Lead also inhibits photosynthesis, lowers mineral nutrition, water balance and enzyme activity [60]. Lead-contaminated soils cause a sharp decline in crop productivity, thus creating a serious problem for agriculture [61]. However, Blaylock et al. [62] reported that in growing media, with a $\mathrm{pH}$ between 5.5 and 7.5, $\mathrm{Pb}$ is seldom available to plants, even if they have the genetic capacity to accumulate it. The content of $\mathrm{Pb}$ in the vermicomposts obtained in this study qualifies them for fertilization use because the permissible content of this element in composts in EU countries is set to $45 \mathrm{mg} \mathrm{kg}^{-1}$ [51].

The largest significant increase in the concentration between the initial biomass and the vermicomposts in both technologies was found for $\mathrm{Cu}$ (PS increase of $105.8 \%$, NPS increase of $111.2 \%$; $p<0.05$ ) and Zn (PS increase of $165.1 \%$, NPS increase of $188.2 \% ; p<0.05$ ) (Table 4). Similar results were demonstrated by Gong et al. [63], who, by vermicomposting mushroom substrate and cattle manure, obtained an increase in $\mathrm{Cu}(35.6-62.4 \%)$ and $\mathrm{Zn}(27.4-91.1 \%)$. By contrast, Soobhany et al. [64] found a reduction in the $\mathrm{Cu}$ content in vermicompost in research on the vermicomposting of mixed organic waste. The analyzed elements at the appropriate concentration are important micronutrients for plant development. Zinc is a component of many proteins and is essential for optimal plant 
growth and development [65]. However, at high concentrations in soil, $\mathrm{Zn}$ is phytotoxic, and plants that accumulate it pose a threat to the health of consumers [66]. The contents of $\mathrm{Cu}$ and $\mathrm{Zn}$ in the vermicomposts obtained cannot be considered toxic for plants and do not eliminate vermicomposts for fertilization because they are within the permissible limits ( $\mathrm{Cu}$ up to $70 \mathrm{mg} \mathrm{kg}^{-1}$, Zn up to $200 \mathrm{mg} \mathrm{kg}^{-1}$ ) in composts in EU countries [51].

There was also an increase in the Cd content in the vermicomposts obtained compared to the initial biomass (in both PS and NPS technologies, an increase of 28.6\%; $p<0.05$ ) (Table 4). The opposite results were obtained by Soobhany et al. [64], who demonstrated a reduction in Cd concentration in the vermicomposting of organic waste. Cadmium is described as one of the most toxic heavy metals in the environment and has a negative impact on plants and animals [67]. The high content of Cd in the soil may cause the degradation effects on crops, e.g., disturbances in the photosynthesis process, the inhibition of cell division, which may result in the inhibition of plant growth and a significant reduction in yields $[68,69]$. A low content of $\mathrm{Cd}$ in the soil does not necessarily eliminate the negative impact of this element on the health of animals and humans because $\mathrm{Cd}$, like $\mathrm{Pb}$, may undergo the process of bio-magnification in food chains, at the top of which are farm animals and humans. The content of $\mathrm{Cd}$ in the vermicomposts produced in this study does not eliminate their fertilization use in agriculture because the permissible content of this element in composts intended for agricultural purposes in the EU countries is $1 \mathrm{mg} \mathrm{kg}^{-1}$ [51].

\section{Conclusions}

This study was carried out to verify whether the use of a protective substrate in the construction of vermireactors can play a positive role in saving the earthworms in the event of the accidental administration of waste- unfavorable for these invertebrates - to vermicomposting; how it would affect the development of E. fetida population and the selected features of the obtained vermicompost. The results presented in the paper show that the use of PS technology can prevent the degradation of the earthworm population, positively influencing their reproduction, and thus the population development. The vermicompost obtained as a result of the research, due to the relatively low concentrations of heavy metals and high content of nutrients, can be used as a fertilizer in the cultivation of not only ornamental but also plants for human consumption.

The biotechnology of organic waste vermicomposting in vermireactors, presented in the work, should be disseminated, because it can be a valuable element of the circular economy concept. It is part of building a strategically justified organization of waste management.

Author Contributions: Conceptualization, G.P.; methodology, G.P.; investigation, G.P., A.M.-P., M.G., J.K. and K.R.B.; data curation, A.M.-P. and M.G.; writing-original draft preparation, G.P.; writing-review and editing, G.P., J.K. and K.R.B.; All authors have read and agreed to the published version of the manuscript.

Funding: The project is financed under the program of the Minister of Science and Higher Education under the name "Regional Initiative of Excellence" in the years 2019-2022 project number 026/RID/2018/19 funding amount PLN 9542500.00 .

Conflicts of Interest: The authors declare no conflict of interest.

\section{References}

1. Zorpas, A.A. Strategy development in the framework of waste management. Sci. Total Environ. 2020, 716. [CrossRef]

2. Suthar, S. Potential utilization of guar gum industrial waste in vermicompost production. Bioresour. Technol. 2006, 97, 2474-2477. [CrossRef] [PubMed]

3. Gong, X.; Li, S.; Carson, M.A.; Chang, S.X.; Wu, Q.; Wang, L.; An, Z.; Sun, X. Spent mushroom substrate and cattle manure amendments enhance the transformation of garden waste into vermicomposts using the earthworm Eisenia fetida. J. Environ. Manag. 2019, 248, 109263. [CrossRef] [PubMed] 
4. Nogales, R.; Domínguez, J.; Mato, S. Vermicompostaje. In Compostaje; Moreno, J., Moral, R., Eds.; Ediciones Mundi Prensa: Madrid, Spain, 2008; pp. 187-208.

5. Huang, K.; Li, F.; Wei, Y.; Chen, X.; Fu, X. Changes of bacterial and fungal community compositions during vermicomposting of vegetable wastes by Eisenia foetida. Bioresour. Technol. 2013, 150, 235-241. [CrossRef] [PubMed]

6. Castillo, J.M.; Romero, E.; Nogales, R. Dynamics of microbial communities related to biochemical parameters during vermicomposting and maturation of agroindustrial lignocellulose wastes. Bioresour. Technol. 2013, 146, 345-354. [CrossRef] [PubMed]

7. Hanc, A.; Chadimova, Z. Nutrient recovery from apple pomace waste by vermicomposting technology. Bioresour. Technol. 2014, 168, 240-244. [CrossRef] [PubMed]

8. Swarnam, T.P.; Velmurugan, A.; Pandey, S.K.; Dam Roy, S. Enhancing nutrient recovery and compost maturity of coconut husk by vermicomposting technology. Bioresour. Technol. 2016, 207, 76-84. [CrossRef]

9. Hanc, A.; Dreslova, M. Effect of composting and vermicomposting on properties of particle size fractions. Bioresour. Technol. 2016, 217, 186-189. [CrossRef]

10. Sonia, V.; Felix, S.; Antony, C. Comparative study of growth and reproduction of earthworm Eudrilus eugeniae in different organic substrate. Int. J. Appl. Sci. 2016, 4, 2455-4499. [CrossRef]

11. Taeporamaysamai, O; Ratanatamskul, C. Co-composting of various organic substrates from municipal solid waste using an on-site prototype vermicomposting reactor. Int. Biodeterior. Biodegrad. 2016, 113, 357-366. [CrossRef]

12. Pączka, G.; Mazur-Pączka, A.; Garczyńska, M.; Podolak, A.; Szura, R.; Butt, K.R.; Kostecka, J. Using of earthworms Eisenia fetida (Sav.) for vermicomposting expansive littoral plants biomass. Appl. Sci. 2019, 9, 3635. [CrossRef]

13. Singh, J.; Kalamdhad, A.S. Reduction of bioavailability and leachability of heavy metals during vermicomposting of water hyacinth. Environ. Sci. Pollut. Res. 2013, 20, 8974-8985. [CrossRef] [PubMed]

14. Xie, D.; Wu, W.; Hao, X.; Jiang, D.; Li, X.; Bai, L. Vermicomposting of sludge from animal wastewater treatment plant mixed with cow dung or swine manure using Eisenia fetida. Environ. Sci. Pollut. Res. 2016, 23, 7767-7775. [CrossRef]

15. Molina, M.J.; Soriano, M.D.; Ingelmo, F.; Llinares, J. Stabilisation of sewage sludge and vinasse bio-wastes by vermicomposting with rabbit manure using Eisenia fetida. Bioresour. Technol. 2013, 137, 88-97. [CrossRef]

16. Sharma, K.; Garg, V.K. Comparative analysis of vermicompost quality produced from rice straw and paper waste employing earthworm Eisenia fetida (Sav.). Bioresour. Technol. 2018, 250, 708-715. [CrossRef] [PubMed]

17. Sharma, K.; Garg, V.K. Recycling of lignocellulosic waste as vermicompost using earthworm Eisenia fetida. Environ. Sci. Pollut. Res. 2019, 26, 14024-14035. [CrossRef]

18. Negi, R.; Suthar, S. Degradation of paper mill wastewater sludge and cow dung by brown-rot fungi Oligoporus placenta and earthworm (Eisenia fetida) during vermicomposting. J. Clean. Prod. 2018, 201, 842-852. [CrossRef]

19. Duncan, I.J.H.; Fraser, D. Understanding Animal Welfare. In Animal Welfare; Appleby, M.C., Hughes, B.O., Eds.; CAB International: Wallingford, UK, 1997; pp. 19-31.

20. Fraser, D.; Weary, D.M.; Pajor, E.A.; Milligan, B.N. A scientific conception of animal welfare that reflects ethical concerns. Anim. Welf. 1997, 6, 187-205.

21. Steffen, G.P.K.; Antoniolli, Z.I.; Steffen, R.B.; Jacques, R.J.S.; dos Santos, M.L. Earthworm extraction with onion solution. Appl. Soil Ecol. 2013, 69, 28-31. [CrossRef]

22. MAFF. The Analysis of Agricultural Materials: A Manual of the Analytical Methods Used by the Agricultural Development and Advisory Service (ADAS); HMSO: London, UK, 1981.

23. Sangwan, P.; Kaushik, C.P.; Garg, V.K. Vermiconversion of industrial sludge for recycling the nutrients. Bioresour. Technol. 2008, 99, 8699-8704. [CrossRef]

24. Flack, F.M.; Hartenstein, R. Growth of the earthworm Eisenia fetida on microorganisms and cellulose. Soils Biol. Biochem. 1984, 16, 491-495. [CrossRef]

25. Suthar, S. Nutrient changes and biodynamics of epigeic earthworm Perionyx excavatus (perrier) during recycling of some agriculture wastes. Bioresour. Technol. 2007, 98, 1608-1614. [CrossRef] [PubMed]

26. Reinecke, S.A.; Prinsloo, M.W.; Reinecke, A.J. Resistance of Eisenia fetida (Oligochaeta) to cadmium after long-term exposure. Ecotoxicol. Environ. Saf. 1999, 42, 75-80. [CrossRef] 
27. Takacs, V.; Molnar, L.; Klimek, B.; Galuszka, A.; Morgan, A.J.; Plytycz, B. Exposure of Eisenia andrei (Oligochaeta; Lumbricidea) to cadmium polluted soil inhibits earthworm maturation and reproduction but not restoration of experimentally depleted coelomocytes or regeneration of amputated segments. Folia Biol. 2016, 64, 275-284. [CrossRef] [PubMed]

28. Spurgeon, D.J.; Hopkin, S.P. The development of genetically inherited resistance to zinc in laboratory-selected generations of the earthworm Eisenia fetida. Environ. Pollut. 2000, 109, 193-201. [CrossRef]

29. Neuhauser, E.F.; Meyer, J.A.; Malecki, M.R.; Thomas, J.R. Dietary cobalt supplements and the growth and reproduction of the earthworm Eisenia fetida. Soil Biol. Biochem. 1984, 16, 521-523. [CrossRef]

30. Van Gestel, C.A.M.; van Dis, W.A.; van Breemen, E.M.; Sparenburg, P.M.; Baerselman, R. Influence of cadmium, copper and pentachlorophenol on growth and sexual development of Eisenia andrei (Oligochaeta Annelida). Biol. Fertil. Soils 1991, 12, 117-121. [CrossRef]

31. Klok, C.; De Roos, A.M. Population level consequences of toxicological influences on individual growth and reproduction in Lumbricus rubellus (Lumbricidae, Oligochaeta). Ecotoxicol. Environ. Saf. 1996, 33, 118-127. [CrossRef]

32. Ma, W. Sublethal toxic effects of copper on growth, reproduction and litter breakdown in the earthworm Lumbricus rubellus, with observations on the influence of temperature and soil $\mathrm{pH}$. Environ. Pollut. Ser. A 1984, 33, 207-219. [CrossRef]

33. Owojori, O.J.; Reinecke, A.J.; Rozanov, A.B. The combined stress effects of salinity and copper on the earthworm Eisenia fetida. Appl. Soil Ecol. 2009, 41, 277-285. [CrossRef]

34. Fischer, E.; Molnar, L. Growth and reproduction of Eisenia fetida (Oligochaeta, Lumbricidae) in various metal chlorides containing semi-natural soil. Soil Biol. Biochem. 1997, 29, 667-670. [CrossRef]

35. Huang, K.; Fusheng, L.; Yongfen, W.; Xiaoyong, F.; Xuemin, C. Effects of earthworms on physicochemical properties and microbial profiles during vermicomposting of fresh fruit and vegetable wastes. Bioresour. Technol. 2014, 170, 45-52. [CrossRef]

36. Bhat, S.A.; Singh, J.; Vig, A.P. Effect on Growth of Earthworm and Chemical Parameters during Vermicomposting of Pressmud Sludge Mixed with Cattle Dung Mixture. Procedia Environ. Sci. 2016, 35, 425-434. [CrossRef]

37. Ndegwa, P.M.; Thompson, S.A. Integrating composting and vermicomposting in the treatment and bioconversion of biosolids. Bioresour. Technol. 2001, 76, 107-112. [CrossRef]

38. Pramanik, P.; Ghosh, G.K.; Ghosal, P.K.; Banik, P. Changes in Organic-C, N, P and K and enzyme activities in vermicomposts of biodegradable organic wastes under liming and microbial inoculants. Bioresour. Technol. 2007, 98, 2485-2494. [CrossRef] [PubMed]

39. Kaviraj, S.S.; Sharma, S. Municipal solid waste management through vermicomposting employing exotic and local species of earthworms. Bioresour. Technol. 2003, 90, 169-173. [CrossRef]

40. Suthar, S. Bioremediation of aerobically treated distillery sludge mixed with cow dung by using an epigeic earthworm Eisenia fetida. Environmentalist 2008, 28, 76-84. [CrossRef]

41. Viel, M.; Sayag, D.; Peyre, A.; Andre, L. Optimization of In-vessel Co-composting through heat recovery. Biol. Wastes 1987, 20, 167-185. [CrossRef]

42. Plaza, C.; Nogales, R.; Senesi, N.; Benitez, E.; Polo, A. Organic matter humification by vermicomposting of cattle manure alone and mixed with two-phase olive pomace. Bioresour. Technol. 2007, 9, 5085-5089. [CrossRef]

43. Deka, H.; Deka, S.; Baruah, C.K.; Das, J.; Hoque, S.; Sarma, H.; Sarma, N.S. Vermicomposting potential of Perionyx excavates for recycling of waste biomass of java citronella-An aromatic oil yielding plant. Bioresour. Technol. 2011, 102, 11212-11217. [CrossRef]

44. Ghosh, M.; Chattopadhyay, G.N.; Baral, K. Transformation of phosphorus during vermicomposting. Bioresour. Technol. 1999, 69, 149-154. [CrossRef]

45. Prakash, M.; Karmegam, N. Dynamics of nutrients and microflora during vermicomposting of mango leaf litter (Mangifera indica) using Perionyx ceylanensis. Int. J. Glob. Environ. Issues 2010, 10, 339-353. [CrossRef]

46. Suthar, S.; Pandey, B.; Gusain, R.; Gaur, R.Z.; Kumar, K. Nutrient changes and biodynamics of Eisenia fetida during vermicomposting of water lettuce (Pistia sp.) biomass: A noxious weed of aquatic system. Environ. Sci. Pollut. Res. 2017, 24, 199-207. [CrossRef] [PubMed] 
47. Suthar, S.; Sharma, P. Vermicomposting of toxic weed-Lantana camara biomass: Chemical and microbial properties changes and assessment of toxicity of end product using seed bioassay. Ecotoxicol. Environ. Saf. 2013, 95, 179-187. [CrossRef]

48. Puyuelo, B.; Arizmendiarrieta, J.S.; Irigoyen, I.; Plana, R. Quality assessment of composts officially registered as organic fertilisers in Spain. Span. J. Agric. Res. 2019, 17, 1101. [CrossRef]

49. Das, D.; Bhattacharyya, P.; Ghosh, B.C.; Banik, P. Effect of vermicomposting on calcium, sulphur and some heavy metal content of different biodegradable organic wastes under liming and microbial inoculation. J. Environ. Sci. Health B 2012, 47, 205-211. [CrossRef]

50. Liu, X.; Hu, C.; Zhang, S. Effects of earthworm activity on fertility and heavy metal bioavailability in sewage sludge. Environ. Int. 2005, 31, 874-879. [CrossRef]

51. Heavy Metals and Organic Compounds from Wastes Used as Organic Fertilizers. Annex 2 Compost Quality Definition-Legislation and Standards. Available online: http://ec.europa.eu/environment/waste/compost/ pdf/hm_annex2.pdf (accessed on 7 August 2020).

52. Deolalikar, A.V.; Mitra, A.; Bhattacharyee, S.; Chakraborty, S. Effect of vermicomposting process on metal content of paper mill solid waste. J. Environ. Sci. Eng. 2005, 47, 81-84. [PubMed]

53. Hait, S.; Tare, V. Transformation and availability of nutrients and heavy metalsduring integrated composting-vermicomposting of sewage sludge. Ecotoxicol. Environ. Saf. 2012, 79, 214-224. [CrossRef] [PubMed]

54. Yuvaraj, A.; Thangaraj, R.; Maheswaran, R. Decomposition of poultry litter through vermicomposting using earthworm Drawida sulcata and its effect on plant growth. Int. J. Environ. Sci. Technol. 2019, 16, 7241-7254. [CrossRef]

55. Bhat, S.A.; Singh, J.; Vig, A.P. Vermiremediation of dyeing sludge from textile mill with the help of exotic earthworm Eisenia fetida Savigny. Environ. Sci. Pollut. Res. 2013, 20, 5975-5982. [CrossRef]

56. Gupta, R.; Garg, V.K. Stabilization of primary sewage sludge during vermicomposting. J. Hazard. Mater. 2008, 153, 1023-1030. [CrossRef]

57. Li, L.; Xu, Z.; Wu, J.; Tian, G. Bioaccumulation of heavy metals in the earthworm Eisenia fetida in relation to bioavailable metal concentrations in pig manure. Bioresour. Technol. 2010, 101, 3430-3436. [CrossRef]

58. Singh, J.; Kalamdhad, A.S. Assessment of bioavailability and leachability of heavy metals during rotary drum composting of green waste (Water hyacinth). Ecol. Eng. 2013, 52, 59-69. [CrossRef]

59. Mukhopadhyay, M.; Sharma, A. Manganese in cell metabolism of higher plants. Bot. Rev. 1991, 57, 117-149. [CrossRef]

60. Sharma, P.; Dubey, R.S. Lead toxicity in plants. Braz. J. Plant Physiol. 2005, 17, 35-52. [CrossRef]

61. Johnson, M.S.; Eaton, J.W. Environmental contamination through residual trace metal dispersal from a derelict lead-zinc mine. J. Environ. Qual. 1980, 9, 175-179. [CrossRef]

62. Blaylock, M.J.; Salt, D.E.; Dushenkov, S.; Zakarova, O.; Gussman, C.; Kapulnik, Y.; Ensley, B.D.; Raskin, I. Enhanced accumulation of $\mathrm{Pb}$ in Indian mustard by soil-applied chelating agents. Environ. Sci. Technol. 1997, 31, 860-865. [CrossRef]

63. Gong, X.Q.; Li, S.Y.; Chang, S.X.; Wu, Q.; Cai, L.L.; Sun, X.Y. Alkyl polyglycoside and earthworm (Eisenia fetida) enhance biodegradation of green waste and its use for growing vegetables. Ecotoxicol. Environ. Saf. 2019, 167, 459-466. [CrossRef]

64. Soobhany, N.; Mohee, R.; Garg, V.K. Comparative assessment of heavy metals content during the composting and vermicomposting of Municipal Solid Waste employing Eudrilus eugeniae. Waste Manag. 2015, 39, $130-145$. [CrossRef]

65. Broadley, M.R.; White, P.J.; Hammond, J.P.; Zelko, I.; Lux, A. Zinc in plants. New Phytol. 2007, 173, 677-702. [CrossRef] [PubMed]

66. Bolan, N.; Kunhikrishnan, A.; Thangarajan, R.; Kumpiene, J.; Park, J.; Makino, T.; Kirkham, M.B.; Scheckel, K. Remediation of heavy metal(loid)s contaminated soils-To mobilize or to immobilize? J. Hazard. Mater. 2014, 266, 141-166. [CrossRef] [PubMed]

67. Wang, J.; Jiang, Y.; Sun, J.; She, J.; Yin, M.; Fang, F.; Liu, J. Geochemical transfer of cadmium in river sediments near a lead-zinc smelter. Ecotoxicol. Environ. Saf. 2020, 196, 110529. [CrossRef] [PubMed] 
68. Rizwan, M.; Ali, S.; Adrees, M.; Ibrahim, M.; Tsang, D.C.; Zia-ur-Rehman, M.; Zahir, Z.A.; Rinklebe, J.; Tack, F.M.G.; Ok, Y.S. A critical review on effects, tolerance mechanisms and management of cadmium in vegetables. Chemosphere 2017, 182, 90-105. [CrossRef]

69. Rizwan, M.; Ali, S.; Hussain, A.; Ali, Q.; Shakoor, M.B.; Zia-ur-Rehman, M.; Asma, M. Effect of zinc-lysine on growth, yield and cadmium uptake in wheat (Triticum aestivum L.) and health risk assessment. Chemosphere 2017, 187, 35-42. [CrossRef]

Publisher's Note: MDPI stays neutral with regard to jurisdictional claims in published maps and institutional affiliations.

(C) 2020 by the authors. Licensee MDPI, Basel, Switzerland. This article is an open access article distributed under the terms and conditions of the Creative Commons Attribution (CC BY) license (http://creativecommons.org/licenses/by/4.0/). 